\title{
Entrepreneurship Development Policymaking Factors: An exploratory survey of Tourism in Iran
}

\author{
Jafari Moghaddam Saeed ${ }^{17}$, Zali Mohammad Reza ${ }^{18}$, Sanaeepour Haditi
}

\begin{abstract}
Widespread presence of small and medium enterprise (SME) and entrepreneurial businesses (EB) as well as governments' key role in tourism sphere, especially in developing countries. As a result, the importance of policymaking in SME and EB has been growing through last decade. This study is trying to identify and prioritize the factors influencing SME and EB policy in Iran tourism scope. For this research, data were collected via exploratory mixed method in two steps. Firstly, qualitative techniques such as literature review has been done to find all scholarly work and then using qualitative content analysis, factors influencing SME policy in tourism has been identified. In second step, quantitative methods, namely survey and Statistical techniques were used for analysis. Population of this study comprised policymaking and tourism entrepreneurship experts of Iran. The survey results showed there were 40 variables into six factors under two main dimensions influence on SME and EB. Factors indentified in this study can be used to formulate macro policies in the tourism industry and national policymakers can utilize these concepts for entrepreneurship and SME's development in tourism. This research contributes to the existing literature in the field of entrepreneurship policymaking by introduce a systematic framework. This new framework can provide better insights and inform thinking in the area of entrepreneurship policymaking.
\end{abstract}

KEY WORDS: Entrepreneurship Development, Policymaking, Entrepreneurial Businesses (EB), Tourism, Exploratory Mixed Method

JEL: L26, L53,L83

UDC: $005.342: 338.48(55)$

005.311.11:303.62

COBISS.SR-ID 238310412

${ }^{17}$ Department of Entrepreneurship Development, Faculty of Entrepreneurship, University of Tehran, Tehran, Iran

${ }^{18}$ Department of Corporate Entrepreneurship, Faculty of Entrepreneurship, University of Tehran, Tehran, Iran

${ }^{19}$ Department of Entrepreneurship Development, Faculty of Entrepreneurship, University of Tehran, Tehran, Iran, e-mail: hadisanaeepour@ut.ac.ir 


\section{INTRODUCTION}

Nowadays, the amazing growth of tourism industry led to a systematic increase the share of tourism in GDP (Najda-Janoszka and Kopera, 2014). Tourism has become an affecting phenomenon in the global economy and in many countries, the main source of income and employment generation, private sector growth and development of the infrastructure. On average, $9 \%$ of GDP generated from tourism, one of every 11 jobs and $30 \%$ of services exports devoted to tourism (UNWTO, 2015).

The Previous studies show that tourism has been growing over time and to become one of the largest and fastest-growing economic sectors in the world. However economic shocks happened periodically, but tourism has shown virtually uninterrupted growth. International tourist arrivals and international tourism receipts earned by destinations have increased. Also in long-term outlook, International tourist arrivals worldwide are expected to increase by $3.3 \%$ a year between 2010 and 2030 to reach 1.8 billion by 2030, according to UNWTO's long term forecast Tourism Towards 2030. Thus, the importance of tourism as a mechanism for economic development enhanced and the government should not ignore this opportunity.

Development of entrepreneurship and SME's has created unique benefits for society such as employment growth, economic diversification and increase the speed of social and economic development (Akbaba, 2012). Also, tourism has provided the ability of market opportunity identification and products development and created new opportunities for the use of resources (Lordkipanidze, 2005). Thus, governments design and develop policies to support entrepreneurial activity and encouraging people to create the business in tourism (Saufi, 2013).

On the other hand, in recent decades, entrepreneurship has become one of the key issues for policy makers (Norback et al., 2014). Entrepreneurship as an engine of economic growth and social development has introduced (Tsai and Kuo, 2011) and policy-makers looking for set up dynamic and competitive entrepreneurial economy (Stevenson and Lundstrum, 2001). Reports show that about $30 \%$ difference in the rate of GDP growth, due to differences in the level of entrepreneurial activity (Audretsch et al., 2002).

Tourism is very complex phenomenon that composed from economic and political factors (Garcia, 2014) and drives economic and social progress (Najda-Janoszka and Kopera, 2014), therefore policy making to exploit the opportunities provided by tourism, has turned to one of the most important duties of governments. On the other hand, unplanned tourism development causes the excessive and inappropriate use of resources, and that does not comply with the principles of sustainable development (Gunawardana and Sanjeewani, 2009).

Although, tourism is one of the pillars of the world economy (UNWTO, 2015), the exploitation of its diverse and pervasive opportunities requires appropriate conditions which primarily could be introduced by its influential factors on it. Therefore, the main goal of this study is recognizing the most important factors on entrepreneurship policy in tourism. And, how it can be integrated pattern of factors affecting the development of entrepreneurship in tourism adjusted due to differences in levels of development among different regions.

Evidence shows that despite multiple studies in entrepreneurship policy and tourism, researchers have been neglected the policy-making process for the development of tourism businesses and tourism entrepreneurship (Saufi, 2013 and Thomas et al., 2011), and studies have not systematic framework and each study has been paid attention to limited aspects for tourism policy. So it should be done more studies and theoretical contributions to development of entrepreneurship in the tourism (Thomas et al., 2011). Therefore, the contribution of this research is providing a comprehensive framework for entrepreneurship policy in tourism. 


\section{THEORETICAL FOUNDATIONS}

There are various definitions of the policy. In summary, Policy is a relatively stable and purposeful action provided by a person or group of actors for a public problem or general concern (Anderson, 2000). Tourism policy is an interdisciplinary field and there are various definitions. Hall and Jenkins (1995) believe tourism policy is all the things that governments do or do not do in tourism. To ensure the effectiveness of the policies, tourism should be developed consistent with economic and social goals and appropriate mechanisms and process to ensure the development of this industry (Sharpley, 2008).

Entrepreneurship policy guide productive social and economic activities for businesses (Rigby and Ramlogan, 2013), and means for promoting entrepreneurship in society. Entrepreneurship policy focused on before and after steps the launch businesses in the entrepreneurial process (Stevenson and Lundstrum, 2001). Policy entrepreneurship, a new approach to policy making that focuses on individuals and small businesses and against on the traditional policies that focus on large companies (Norback et al., 2014).

The first studies in the field of entrepreneurship policy conducted with Birch in 1979. In their study showed that most new jobs in the United States created by small businesses. SME's policy has been transformed at the end of the 1980s and early 1990s. In these years formulating policies focus on improve the operational environment for small firms, and generally ignored the issue of creating new companies (Stevenson and Lundström, 2007).

In this time, Research documents and researches point to the important role of small businesses to create new jobs and innovative activity. During this period, policymakers have emphasized that small and new companies require policy support (Henrekson and Stenkula, 2010).

Entrepreneurship policy not only for job creation but also used to innovation, the growth of productivity and economic restructuring. Entrepreneurship policy changing the direction of managed economy to entrepreneurial economy. Entrepreneurial economy typically contains the transition from an industrial economy to a knowledge-based economy, from manufacturing to services, from focusing on big companies to focus on small and new companies (Stevenson and Lundstrum, 2001). It shifts attention from companies to individuals, self-employed to effective entrepreneurs, increases the quantity to improve the quality, and of people's support to empower them (Henrekson and Stenkula, 2010).

Entrepreneurship policies contain correcting macroeconomics, reform exchange rate, trade and industrial policy corrections and improve the governance. Entrepreneurship policy also can be used for poverty reduction (Acs and Virgil, 2010). Because policies affect entrepreneurial activities, thus encouraging entrepreneurial activities highly regarded with emphasis on innovative entrepreneurs (Henrekson and Stenkula, 2010). A well-designed policy entrepreneurship, facilitate effective entrepreneurial activities (Acs and Szerb, 2007).

\section{GLOBAL ENTREPRENEURSHIP MONITOR MODEL}

A proper framework for entrepreneurship policy development is entrepreneurship ABC model. This model Consists of three-section: attitudes, behaviors, and consequences (Bosma, 2008). An entrepreneurial attitude is an inner propensity to entrepreneurship. Attitudes and potential entrepreneurs are people who have positive beliefs about entrepreneurship. Attitudes push a person towards entrepreneurship and lead to the formation of the entrepreneurial intention (Bosma, 2008). Attitudes have a direct relationship with behaviors based on the 
Attitudes, behaviors can be predicted. Entrepreneurial behaviors, activities related to the launch and manage the new business that budding entrepreneurs first and then stabilized. Entrepreneurial results represent the results of entrepreneurial activities after the launch of new businesses by entrepreneurs and representing business growth or high growth expected entrepreneurship in the new market or new products, and high-tech entrepreneurship (Bosma, 2008). In this study, factors affecting the development of entrepreneurship in three levels, attitudes, behaviors and consequences identified and classified.

\section{ENTREPRENEURIAL ENVIRONMENT FACTORS}

Another part of the survey is the Porter (2000) entrepreneurial environment factors. In this theory, economic development occurred in three levels: Factor-driven, Efficiency-driven, Innovation-driven stage. Since for the comprehensive entrepreneurship policy; attention to levels of development will be helpful and adjusted policies should be based on different levels of economic development; in this study, in addition to identifying and ranking the factors affecting the entrepreneurship policy in tourism, we focused on Entrepreneurial environment factors as crucial factors for policymaking. Therefore, under consideration the interaction between entrepreneurship development factors and entrepreneurial environment factors that which is new and comprehensive.

The factor-driven economy requires establishing the basic requirements for economic development (such as infrastructure, institutions, etc.). It features traditional agriculture, raw materials extraction and hard centralization. The efficiency-driven economy requires improving the efficiency enhancer factors (such as market efficiency and human resources, technological readiness, etc.). Society becomes to Industrializing and benefits caused by large scale production. Large companies dominate the economy, but there is a corner for SME's. The innovation-driven economy is also innovation driving factors (such as research and development, property rights, etc.). In this stage, Knowledge-based economy and services, developed and innovative entrepreneurial activities is higher (Acs, et al., 2016).

Since exists a significant gap in the relationship between entrepreneurship and economic growth (Grilo and Thurik, 2006), policymakers should regard to the level of economic development. Therefore, for comprehensive entrepreneurship policy; attention to levels of development of the entrepreneurial environment factors will be helpful. In this respect, we focused on three level of economic development because the factors for economic development at different stages are different (Acs and Szerb, 2010). Therefore, adjusted policies for entrepreneurship development should be based on different levels of economic development.

\section{CONCEPTUAL FRAMEWORK}

In this research, for identifying and Prioritization of entrepreneurship development policymaking factors in tourism we use a combination of tow global model. In one dimension, we use Global Entrepreneurship Monitor (GEM) Model there were entrepreneurship development factors with regard to entrepreneurial attitudes, behaviors and consequences. In other dimension, we use Porter (2000) model there were entrepreneurial environment factors with regard to basic requirements, efficiency enhancers and innovation driver factors. This combination showed in Figure 1. 


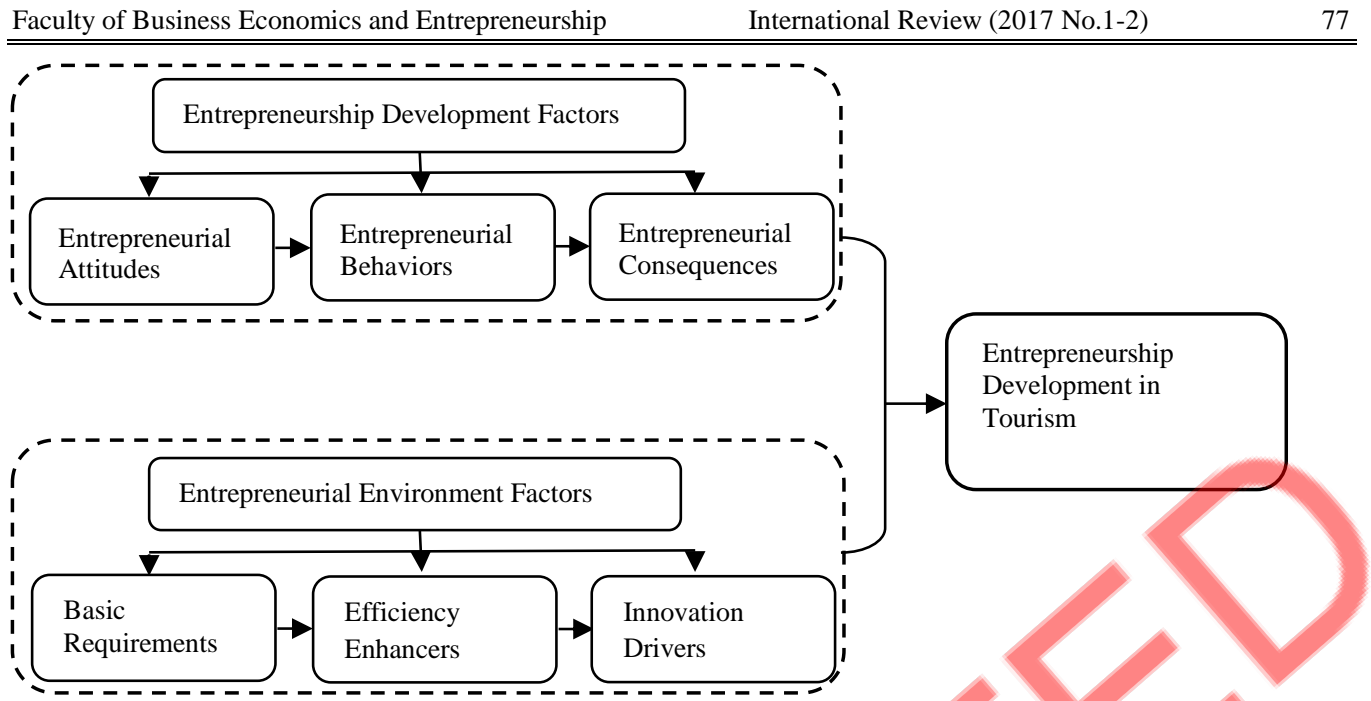

Figure 1: Conceptual Framework for Entrepreneurship policy in Tourism

\section{RESEARCH METHODOLOGY}

This study was done using an exploratory mixed method. Identify the factors of entrepreneurship in tourism policy is the main purpose of this study. To achieve this goal, first, we use qualitative method for identifying factors and then, quantitative methods to confirm the results and prioritize the factors and variables were used. For this study, three steps are anticipated to include in bellow process research.

\section{Step1- Qualitative Phase: Identify and verify the factors and variables}

Qualitative content analysis used in this step, widely used for analyzing text data and done through the process of systematic classification, coding or theme design known patterns. Thus, theory and research, purposeful detected and coded on the basis of a systematic approach. The coding process includes open, axial and selective coding (Strauss and Corbin, 1990).

Open coding, the analysis process through which themes were identified and their characteristics can be found in the data (Flint et al., 2012). In this step, literature reviewed line by line, and themes and basic concepts extracted and then continually review and compare their frequent initial code, the codes with content and common concepts classified under one concept (Padgett, 2004). Axial coding is the process of communicating sub-themes to main themes. This process creates discipline and systematic relationships are usually placed in the data (Strauss and Corbin, 1990). At this point, one of the open coding themes chosen as the main theme and other subjects related to it. In this step, sample selected from research papers, reports, etc. on the subject of research and measurement method has been conducted via coding process. The final phase of this process is selective coding. In selective coding, concepts and themes presented in the previous step classified regular and systematic. In this step, using purposive sampling, researches related to the development of entrepreneurship in tourism were identified. It should be noted that the results of this step has been reviewed by 13 experts in two groups. The first group includes legislators, policymakers, experts and the directors in Department of Tourism Policy Council. The second group includes tourism entrepreneurs and business owners. 


\section{Step 2- Quantitative Phase: Experts Survey}

In this step, results checked out by experts in the field of policymaking, molding, and tourism. Measurement method has been conducted by questionnaire. Selected samples for implementation the normality of the data and one-sample T-test are 14 experts. In this step, to rank the listed components, we use $\chi^{2}$ test run and Friedman variance analysis ranking test.

\section{DATA ANALYSIS}

\section{Step1- Qualitative Phase: Identify and verify the factors and variables}

Analysis begins with a review of published literature. Line-by-line published literature review on the subject; identified 423 open codes and could classify in the form of 85 axial codes. At the end of this process, axial codes classified to 40 selective codes. Ultimately main themes for tourism entrepreneurship policy were extracted. Results of this step presented in Table 1.

Table 1: Dimensions, factors and variables identified for Entrepreneurship policy in tourism

\begin{tabular}{|c|c|c|}
\hline Main dimensions & Policy factors & Relevant variables \\
\hline \multirow{39}{*}{$\begin{array}{l}\text { Entrepreneurship } \\
\text { Development Factors }\end{array}$} & \multirow{6}{*}{$\begin{array}{l}\text { Entrepreneurial } \\
\text { Attitudes }\end{array}$} & The ability to opportunity perception \\
\hline & & Entrepreneurial self-efficacy \\
\hline & & Risk-seeking \\
\hline & & Belief in social ties \\
\hline & & Social status of entrepreneurs \\
\hline & & Entrepreneurial intention \\
\hline & \multirow{13}{*}{$\begin{array}{l}\text { Entrepreneurial } \\
\text { Behaviors }\end{array}$} & Exploitation of opportunities \\
\hline & & Attract and develop new technology \\
\hline & & Improving individual capabilities \\
\hline & & Team building to launch new business \\
\hline & & $\begin{array}{l}\text { Networking } \\
\text { Business plan arrangement }\end{array}$ \\
\hline & & Entrepreneurial leadership \\
\hline & & Innovation in product and service \\
\hline & & Innovations in Process \\
\hline & & Growth (employing up to 20 people in 5 years) \\
\hline & & The internationalization of business \\
\hline & & The risk capital \\
\hline & & Popularity and creditability \\
\hline & & Growth (employment more than 20 people after the first 5 years) \\
\hline & \multirow{4}{*}{ Basic Requirements } & Legal and administrative framework \\
\hline & & Development of infrastructure \\
\hline & & The stability of the business environment \\
\hline & & Essential health care and basic education \\
\hline & \multirow{6}{*}{$\begin{array}{l}\text { Efficiency } \\
\text { Enhancers }\end{array}$} & Product and service market efficiency \\
\hline & & Labor market efficiency \\
\hline & & Sufficient technological readiness \\
\hline & & Higher education \\
\hline & & The efficiency of financial markets \\
\hline & & The effective size of the market \\
\hline & \multirow{10}{*}{ Innovation Drivers } & Financial support \\
\hline & & Entrepreneurship in the public sector \\
\hline & & Intellectual property rights \\
\hline & & R\&D transfer and Innovation Support \\
\hline & & Equal access to infrastructure \\
\hline & & Cultural norms/social supporting entrepreneurs \\
\hline & & Governmental policies in education and entrepreneurship \\
\hline & & Entrepreneurship education \\
\hline & & Effective market entry rules \\
\hline & & Legal and commercial infrastructure support \\
\hline
\end{tabular}




\section{Step 2- Quantitative Phase: Experts Survey}

In this step, to investigate the factors and variables, questionnaire distributed between experts. Questionnaire designed based on the 7 options Likert scale. Then 16 experts have been identified with using purposive and snowball sampling. Ultimately 14 experts responded to the questionnaire. Therefore, return rate was $87.5 \%$. Kolmogorov-Smirnov (K-S) data Normality test used for analyze the normality of data. The results show that a significant level of all variables more than 0.05 . So it can be concluded that the data are normally distributed.

Single sample t-test with SPSS 18 software also been used for analysis expert opinions. The result shows that all proposed aspects and variables, approved by experts. The results of the questionnaire will be presented in more detail in Table 2.

The results show that more than Confidence 95\%, the main dimensions, and factors proposed for tourism entrepreneurship policy are appropriate. Since the mean of dimensions and factors proposed more than 4 , to say the dimensions and factors are acceptable. Also, because the significance level less than $5 \%$ is obtained for all the questions, so the dimensions and factors exploitable to use in tourism entrepreneurship policy.

Table 2: Single sample t-test for proposed variables

\begin{tabular}{|c|c|c|c|c|}
\hline Relevant variables & $\mathrm{N}$ & Mean & $\mathrm{T}$ & $\begin{array}{l}\text { Sig. }(2- \\
\text { tailed) }\end{array}$ \\
\hline The ability to opportunity perception & 14 & 6.0000 & 7.789 & .000 \\
\hline Entrepreneurial self-efficacy & 14 & 5.5714 & 6.271 & .000 \\
\hline Risk-seeking & 14 & 5.9286 & 5.687 & .000 \\
\hline Belief in social ties & 14 & 5.2857 & 4.225 & .001 \\
\hline Social status of entrepreneurs & $14 \div$ & 5.5714 & 7.778 & .000 \\
\hline Entrepreneurial intention & 14 & 6.1429 & 12.093 & .000 \\
\hline Exploitation of opportunities & 14 & 6.2857 & 10.361 & .000 \\
\hline Attract and develop new technology & 14 & 5.5000 & 5.508 & .000 \\
\hline Improving individual capabilities & 14 & 6.5000 & 14.381 & .000 \\
\hline Team building to launch new business & 14 & 6.0000 & 6.360 & .000 \\
\hline Networking & 14 & 6.0000 & 7.789 & .000 \\
\hline Business plan arrangement & 14 & 5.4286 & 3.150 & .008 \\
\hline Entrepreneurial leadership & 14 & 5.8571 & 4.759 & .000 \\
\hline Innovation in product and service & 14 & 6.3571 & 9.496 & .000 \\
\hline Innovations in Process & 14 & 5.9286 & 6.734 & .000 \\
\hline Growth (employing up to 20 people in 5 years) & 14 & 5.9286 & 7.236 & .000 \\
\hline The internationalization of business & 14 & 5.5714 & 4.204 & .001 \\
\hline The risk capital & 14 & 5.4286 & 3.822 & .002 \\
\hline Popularity and creditability & 14 & 5.6429 & 4.600 & .000 \\
\hline $\begin{array}{l}\text { Growth (employment more than } 20 \text { people after the first } \\
5 \text { years) }\end{array}$ & 14 & 5.5714 & 5.785 & .000 \\
\hline Legal and administrative framework & 14 & 6.0714 & 7.233 & .000 \\
\hline Development of infrastructure & 14 & 6.5000 & 12.315 & .000 \\
\hline The stability of the business environment & 14 & 6.2857 & 8.000 & .000 \\
\hline Essential health care and basic education & 14 & 5.7143 & 4.837 & .000 \\
\hline Product and service market efficiency & 14 & 5.7857 & 7.486 & .000 \\
\hline Labor market efficiency & 14 & 6.0000 & 8.532 & .000 \\
\hline Sufficient technological readiness & 14 & 5.4286 & 4.163 & .001 \\
\hline Higher education & 14 & 5.5000 & 4.583 & .001 \\
\hline The efficiency of financial markets & 14 & 5.5000 & 4.583 & .001 \\
\hline The effective size of the market & 14 & 5.5000 & 4.837 & .000 \\
\hline Financial support & 14 & 5.7857 & 5.623 & .000 \\
\hline Entrepreneurship in the public sector & 14 & 5.0000 & 3.606 & .003 \\
\hline Intellectual property rights & 14 & 6.1429 & 9.275 & .000 \\
\hline
\end{tabular}




\begin{tabular}{|c|c|c|c|c|}
\hline Relevant variables & $\mathrm{N}$ & Mean & $\mathrm{T}$ & $\begin{array}{l}\text { Sig. (2- } \\
\text { tailed) }\end{array}$ \\
\hline R\&D transfer and Innovation Support & 14 & 5.9286 & 5.434 & .000 \\
\hline Equal access to infrastructure & 14 & 6.0714 & 6.423 & .000 \\
\hline Cultural norms/social supporting entrepreneurs & 14 & 5.4286 & 3.438 & .004 \\
\hline Governmental policy in education \&entrepreneurship & 14 & 6.0714 & 5.836 & .000 \\
\hline Entrepreneurship education & 14 & 5.5714 & 5.785 & .000 \\
\hline Effective market entry rules & 14 & 5.2857 & 4.225 & .001 \\
\hline Legal and commercial infrastructure support & 14 & 6.0000 & 5.099 & .000 \\
\hline
\end{tabular}

Confidence interval $=0.095$

To rank the listed components, $\chi 2$ test run and became clear that the proposed factors for tourism entrepreneurship policy haven't the same rank. Then according to Friedman variance analysis ranking the proposed factors obtained presented in Table 3.

Table 3: Ranking the proposed variables for entrepreneurship policy according to the experts

\begin{tabular}{|c|c|c|c|c|}
\hline Main dimensions & Policy factors & Relevant variables & $\begin{array}{l}\text { Mean } \\
\text { rank }\end{array}$ & $\begin{array}{l}\text { Total } \\
\text { rank }\end{array}$ \\
\hline \multirow{40}{*}{$\begin{array}{l}\text { Entrepreneurship } \\
\text { Development Factors }\end{array}$} & \multirow{6}{*}{$\begin{array}{l}\text { Entrepreneurial } \\
\text { Attitudes }\end{array}$} & Entrepreneurial intention & 4.25 & 1 \\
\hline & & The ability to opportunity perception & 4.07 & 2 \\
\hline & & Risk-seeking & 3.93 & 3 \\
\hline & & Entrepreneurial self-efficacy & 3.14 & 4 \\
\hline & & Social status of entrepreneurs & 2.96 & 5 \\
\hline & & Belief in social ties & 2.64 & 6 \\
\hline & \multirow{7}{*}{$\begin{array}{l}\text { Entrepreneurial } \\
\text { Behaviors }\end{array}$} & Improving individual capabilities & 5.36 & 1 \\
\hline & & Exploitation of opportunities & 4.57 & 2 \\
\hline & & Team building to launch new business & 3.96 & 3 \\
\hline & & Entrepreneurial leadership & 3.93 & 4 \\
\hline & & Networking & 3.82 & 5 \\
\hline & & Business plan arrangement & 3.29 & 6 \\
\hline & & Attract and develop new technology & 3.07 & 7 \\
\hline & \multirow{7}{*}{$\begin{array}{l}\text { Entrepreneurial } \\
\text { Consequences }\end{array}$} & Innovation in product and service & 5.29 & 1 \\
\hline & & $\begin{array}{l}\text { Growth (employing up to } 20 \text { people in } 5 \\
\text { years) }\end{array}$ & 4.21 & 2 \\
\hline & & Innovations in Process & 4.07 & 3 \\
\hline & & The internationalization of business & 3.79 & 4 \\
\hline & & Popularity and creditability & 3.64 & 5 \\
\hline & & The risk capital & 3.57 & 6 \\
\hline & & Growth (20 employment after first 5 years) & 3.43 & 7 \\
\hline & \multirow{4}{*}{$\begin{array}{l}\text { Basic } \\
\text { Requirements }\end{array}$} & Development of infrastructure & 2.96 & 1 \\
\hline & & Stability of the business environment & 2.71 & 2 \\
\hline & & Legal and administrative framework & 2.32 & 3 \\
\hline & & Essential health care \& basic education & 2.00 & 4 \\
\hline & \multirow{6}{*}{$\begin{array}{l}\text { Efficiency } \\
\text { Enhancers }\end{array}$} & Labor market efficiency & 4.25 & 1 \\
\hline & & Product and service market efficiency & 3.89 & 2 \\
\hline & & Higher education & 3.32 & 3 \\
\hline & & The effective size of the market & 3.29 & 4 \\
\hline & & The efficiency of financial markets & 3.18 & 5 \\
\hline & & Sufficient technological readiness & 3.07 & 6 \\
\hline & \multirow{10}{*}{ Innovation Drivers } & Entrepreneurship in the public sector & 6.75 & 1 \\
\hline & & Intellectual property rights & 6.61 & 2 \\
\hline & & Legal and commercial infrastructure & 6.54 & 3 \\
\hline & & Equal access to infrastructure & 6.32 & 4 \\
\hline & & R\&D transfer and Innovation Support & 5.93 & 5 \\
\hline & & Entrepreneurship education & 5.39 & 6 \\
\hline & & Financial support & 5.14 & 7 \\
\hline & & Cultural norms/social support & 4.89 & 8 \\
\hline & & Effective market entry rules & 4.29 & 9 \\
\hline & & $\begin{array}{l}\text { Governmental policies in education \& } \\
\text { entrepreneurship }\end{array}$ & 3.14 & 10 \\
\hline
\end{tabular}




\section{FINDINGS, DISCUSSION AND DIRECTION FOR FUTURE STUDIES}

\section{Findings}

The aim of this study was to identify the factors and variables of tourism entrepreneurship policy. For the purposes, in this study, the qualitative methods used to identify factors and variables. To confirm the results and prioritize the factors and variables, focus group and quantitative methods have been used. In this study, we used two frameworks to categorize factors. The first framework, the framework of the Global Entrepreneurship Monitor that factors separated into three sections creation and strengthens entrepreneurial attitudes, display entrepreneurial behaviors and improve the rate of entrepreneurial passion (results).

Since the role of entrepreneurship development for a comprehensive policy for entrepreneurship is not enough, so we must the underlying contextual variables for a different level of development. So the framework entrepreneurial environment factors presented by Porter (2000) were used. In this theory, economic development introduced in three levels of economic development: factor-driven, efficiency-driven, and innovation-driven. In total, 40 variables in the form of six factors for the tourism entrepreneurship policy were identified.

Based on results, it is suggested tourism policy and decision makers, formulize national macro policy in the tourism as well as offer indicators for assessing tourism development policies. More attention to the development of entrepreneurship and start-up businesses in the field of tourism and the development of tourism based on cultural and historical capacity and constructive and effective interaction with other countries, other suggestions.

\section{Discussion}

The results of the studies were consistent and in the following with reviewed researches on tourism policy and entrepreneurship policy. For example, Acs, et al. (2914), Acs and Szerb, (2010) and porter (2000), focused on level of economic development for policy making and we identify variables affect entrepreneurship development with regard to three level of economic development (Factor-driven, Efficiency-driven, Innovation-driven stage).

Also in this study we find variables that emphasized by other researchers. Garcia (2014), Redford (2012), Acs and Szerb (2010) and Singer (2007) emphasis on infrastructure development and Acs, et al. (2016), Redford (2012), Jaffar et al (2011) emphasis on education and human development. Other studies have been focused on variables for tourism policy that used in this paper. Due to in each reviewed studies, have been considered several factors entrepreneurship policy, then in this paper, the most important variables separated in six factors under tow dimensions: Entrepreneurship Development Factors (entrepreneurial attitudes; entrepreneurial behaviors and entrepreneurial consequences) and Entrepreneurial Environment Factors (basic requirements; efficiency enhancers and innovation drivers).

The results of this study could provide new insights facing policymakers by using the determined framework; provide the foundation for developing a comprehensive program for promote entrepreneurship in tourism at national level. Also according to the results, policymakers can considering the most important dimensions and factors affecting the development of entrepreneurship in tourism in future policies.

\section{Limitation and implications for further research}

Although there are many studies in entrepreneurship policy and tourism policy, but study of tourism policy with the aim of entrepreneurship development, is new subject for Iranian policy makers. The lack of a comprehensive study that offers most important variables with regards to economic development stage is another limitation. Few experts in entrepreneurship tourism policy and motivate for participation in focus groups, are third important limitation. 
The next limitation is diverse nature, multidimensional and complex of tourism. Due to the findings of this study, suggested items for future researchers are:

- Weighting the identified factors and variables

- Determine the causal relationship between factors and variables

- The formulation of policy statements according to factors and variables

- Prioritizing policy statements and propose practical solutions.

\section{REFERENCES}

[1] Ács, Z., J. Autio, E., Szerb, L. (2016). Global Entrepreneurship Index. The Global Entrepreneurship and Development Institute, Washington, D.C., USA.

[2] Ács, Z., J., \& Szerb, 1. (2007). Entrepreneurship, Economic Growth and Public Policy, Small Business Economics 28, 109-122.

[3] Ács, Z., J.,Virgill, N. (2010). Entrepreneurship in Developing Countries, in ACS, Z., and D. B. Audretsch, (eds). Handbook of Entrepreneurship Research, Chapter 18, Springer, 485-514.

[4] Acs, Zoltán J., Szerb, L. (2010). THE GLOBAL ENTREPRENEURSHIP \& DEVELOPMENT INDEX (GEDI), DRUID Conference at Imperial College Business School, London, UK.

[5] Akbaba, A. (2012). Understanding Small Tourism Businesses: A Perspective from Turkey, Journal of Hospitality and Tourism Management, 19(9), 1-17.

[6] Anderson, J. E. (2000). Public policy making, New York: Houghton Mifflin.

[7] Audrestch, D. B., Thurik, A. R., Verheul, I., Wennekers, S. (Eds.). (2002). Entrepreneurship: Determinants and Policy in a European-US Comparison. Boston, Dodrecht and London: Kluwer.

[8] Audretsch, D. B., Grilo,I., Thurik, A. R. (2007). Explaining entrepreneurship and the role of policy: A Framework, Handbook of Research on Entrepreneurship Policy. Cheltanham: Edward Elgar, 1-17.

[9] Bosma, N., Jones, K., Autio, E., Levie, J. (2008). Global entrepreneurship monitor 2007 executive report. Babson College, London Business School, and Global Entrepreneurship Research Consortium (GERA).

[10]Flint, D., Gammelgaard, B., Manuj, I.,Pohlen, T. L. (2012). A reviewer's guide to the grounded theory methodology in logistics and supply chain management research. International Journal of Physical Distribution and Logistics Management, 794-803.

[11] Garcia, F. A., (2014). A comparative study of the evolution of tourism policy in Spain and Portugal, Tourism Management Perspectives 11, 34-50.

[12] Grilo, I., Thurik, R. (2006). Latent and actual entrepreneurship in Europe and the US: some recent developments, SCALES-paper N200514.

[13] Gunawardana, M. R.,Sanjeewani H.L.G. (2009). Planning implications and sustainability of tourism: a comparative study of Hikkaduwa and Bentotoa, Sri Lanka, Journal of Tourism, Hospitality and Culinary Arts, 67-86.

[14]Henrekson, M., Stenkula, M., (2010). Entrepreneurship and Public Policy, in ACS, Z., and D. B. Audretsch, (eds). Handbook of Entrepreneurship Research, Chapter 21, Springer, 595-637. 
[15] Jaafar, M., Abdul-Aziz, A. R., Maideen, S. A., Mohd, S. Z., (2011). Entrepreneurship in the tourism industry: Issues in developing countries, International J. of Hospitality Management 30, 827-835.

[16]Lordkipanidze, M., Brezet, H., Backman, M. (2005). The Entrepreneurship Factor in Sustainable Tourism Development, Journal of Cleaner Production, (13): 787- 798.

[17] Najda-Janoszka, M., Kopera, S., (2014). Exploring barriers to innovation in tourism industry - the case of southern region of Poland. Procedia - Social and Behavioral Sciences $110,190-201$

[18] Norback, J., Persson, 1., Douhan, R., (2014). Entrepreneurship Policy and Globalization. Journal of Development Economics, doi: 10.1016/j.jdeveco.

[19] Nybakk, E., Hansen, E., (2008). Entrepreneurial attitude, innovation and performance among Norwegian nature-based tourism enterprises, Forest Policy and Economics 10, 473-479.

[20] Padgett, D. (2004). The qualitative research experience: Wadsworth/Thomson Learning.

[21] Redford, T. D., (2012). Entrepreneurship and Public Policy for today and tomorrow's Portuguese Republic", Working paper, Portuguese Studies Program, University of California, Berkeley.

[22] Rigby, J.,Ramlogan, R., (2013). The Impact and Effectiveness of Entrepreneurship Policy. Nesta Working Paper No. 13 (01).

[23] Saufi, A. (2013). Understanding host community's experiences in establishing and developing small tourism enterprises in Lombok, Indonesia, Ph.D. thesis, Griffith University.

[24] Sharpley, R. (2008). Planning for tourism: the case of Dubai. Tourism and Hospitality Planning and Development, 5(1), $13-30$.

[25] Stevenson, L., Lundström, A., (2001). Entrepreneurship policy for the future: best practice factors, Keynote Presentation at the 46th World Conference of the International, Council for Small Business, Taipei, ROC, June 18

[26] Strauss, A.,Corbin, J. (1990). Basics of qualitative research: Grounded theory procedures and techniques. Sage Publications, Inc.

[27] Thomas, R., Shaw, G., Page, S.J. (2011). Understanding small firms in tourism: A perspective on research trends and challenges. Tourism Management, 32(5), 963 - 976.

[28] Tsai, W.H., Kuo, H.C., (2011). Entrepreneurship policy evaluation and decision analysis for SMEs, Expert Systems with Applications 38, 8343-8351.

[29] United Nations World Tourism Organization (UNWTO). (2015). Tourism Highlight, http://www.e-unwto.org/doi/book/10.18111/9789284416899.

\section{Article history:}

- $\quad$ Received 10 February 2017

- $\quad$ Accepted 7 May 2017 